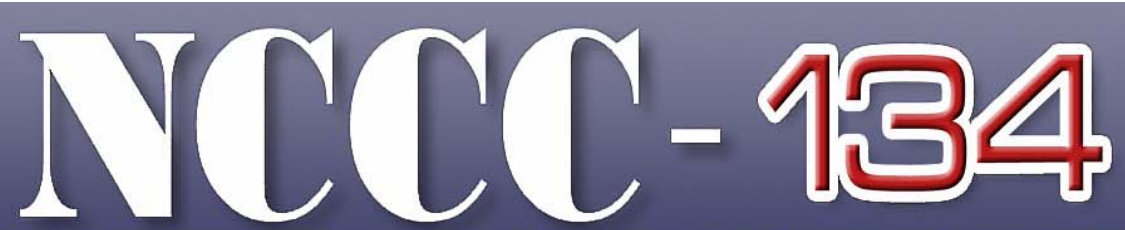

APPLIED COMMODITY PRICE ANALYSIS, FORECASTING AND MARKET RISK MANAGEMENT

\title{
U. S. and Canadian Livestock Prices: Market Integration and Trade Dependence
}

\author{
by
}

Dragan Miljkovic

Suggested citation format:

Miljkovic, D. 2006. "U. S. and Canadian Livestock Prices: Market Integration and Trade Dependence.” Proceedings of the NCCC-134

Conference on Applied Commodity Price Analysis, Forecasting, and Market Risk Management. St. Louis, MO. [http://www.farmdoc.uiuc.edu/nccc134]. 


\title{
U.S. and Canadian Livestock Prices: \\ Market Integration and Trade Dependence
}

\author{
Dragan Miljkovic* \\ Paper presented at the NCCC-134 Conference on Applied Commodity Price \\ Analysis, Forecasting, and Marketing Risk Management \\ St. Louis, MO, April 17-18, 2006
}

Copyright 2006 by Dragan Miljkovic. All rights reserved.

Readers may make verbatim copies of this document for non-commercial purposes by Any means, provided that this copyright notice appears on all such copies.

* Miljkovic is an associate professor, Department of Agribusiness and Applied Economics, North Dakota State University. 


\section{U.S. and Canadian Livestock Prices: Market Integration and Trade Dependence}

\section{Practitioner's Abstract}

Cointegration of Canadian and U.S. livestock prices points to the existence of market integration in the period 1996:1 to 2004:12 even though the trade flows of livestock and beef products were non-existent for many months in 2003 and 2004 (suggesting market segmentation) due to livestock/beef import bans by both countries due to BSE. It was also determined that Canada's trade dependence in livestock and beef is cointegrated with Canadian and U.S. livestock prices. However, as the trade dependence variable is shocked, the effects on Canadian and U.S. prices are opposite although one would expect that in an integrated market the price responses to an exogenous shock would be similar or statistically identical. This result reinforces the case against the use of cointegration in determining presence (or absence) of market integration. Empirical results in this article raise some very difficult questions. Gains from trade are well documented. Yet, once a country is very trade dependent, the prices in it are much more vulnerable to exogenous shocks that reduce the trade flows. Canadian livestock prices plummeted and stayed low following the BSE incident and U.S. (and Japanese) import bans on Canadian livestock and beef. Given the long cycles and high sunk cost in the livestock and beef industry, immediate adjustment (reduction in production) for Canadian producers was difficult and always unlikely. Moreover, the possibility of import bans being lifted in the near future may have further shaped their expectations and prolonged the decisions on herd reduction. In the meanwhile, U.S. prices increased following Canada's trade dependence shock due to BSE and remained above the original long-run equilibrium price.

Keywords: Canada, livestock prices, market integration, trade dependence, United States

\section{Introduction}

Following implementations of Canada-United States Free Trade Agreement (CUSTA) in 1989 and North American Free Trade Agreement (NAFTA) in 1994, Canadian and U.S. markets were expected to become one of the most integrated regional markets in the world. And, to a great extent, these expectations were fulfilled. Canada has become the main trading partner of the United States (Broda and Weinstein, 2004, 2005) surpassing Japan, Germany, and the United Kingdom. Similarly, U.S.-Canada agricultural trade increased by more than four times between early1980s and early 2000s (Miljkovic and Paul, 2003). One of the most dynamic, in terms of trade, sub-sectors of agriculture was the livestock and beef industry. According to Red Meat Yearbook published by the Economic Research Service of the U.S. Department of Agriculture (Economic Research Service), U.S. beef and veal exports to Canada increased from 16,812 thousand pounds of carcass weight in 1983 to 226,325 thousand pounds of carcass weight in 2003, or an increase of more than thirteen times during the twenty-year period. Based on same 
source, U.S. beef and veal imports from Canada more than sextupled between 1983 and 2002 by increasing from 166,385 to 1,090,894 thousand pounds of carcass weight. Moreover, U.S. cattle imports from Canada increased from 338,023 heads in 1981 to $1,686,508$ heads in 2002. Simply put, once trade barriers have been removed, the United States and Canada became "the natural trade partners," to use the notion developed by Frankel, Stein, and Wei, due to geographic proximity and socio-cultural similarities between the two countries.

Concepts of market integration and market efficiency present cornerstones of modern economics. Yet, "the discipline struggles with the important, practical challenges of clearly defining a market empirically and of establishing whether markets are efficient in allocating scarce goods and services” (Barrett 2001, p. 19). Most ordinary people with little or no economics training will define, with no hesitation, product market integration as the situation when a product from one market can and does enter the other market. Some economists and agricultural economists adopt this flow-based definition of market integration (e.g., Barrett 2001; Barrett, Li, and Bailey; Knetter and Slaughter; Krugman; Miljkovic and Paul 2002, 2003). Generally speaking, however, a majority of agricultural economists identifies integration with the "satisfaction of the law of one price (LOP) in some form or another” (Barret 2001, p.19). The LOP states that when prices are converted to a common currency, the same good should sell for the same price (up to the cost of commerce) in different countries once all profitable arbitrage opportunities are extinguished. A standard technique employed for many years in the LOP/market integration studies has been cointegration analysis (e.g., Ardeni; Asche, Bremnes, and Wessels 1999, 2001; Baffes; Goodwin; Zanias). This practice was criticized in several studies (e.g., Barrett 1996, 2001; McNew and Fackler; Lence and Falk; Miljkovic; Miljkovic and Paul 2001) due to its lack of theoretical foundation, but that has hardly stopped the influx of cointegration-based market integration studies. More interestingly, the hypothesis of market integration/LOP has been routinely rejected in the literature ${ }^{1}$ in spite of an obvious and overwhelming increase in volume of international trade during the era of globalization and increased regional trade liberalization. Even further refinements of price-only market integration models such as the threshold cointegration model (e.g., Goodwin and Piggott) are still inappropriate because they rely on strong assumptions about constant transactions costs, continuous trade flows, or both. The same holds true for switching regimes model (e.g., Sexton, Kling, and Carman) which offers only static comparisons and does not allow the analysis of the dynamics of intertemporal adjustment to short-run deviations from long-run equilibrium.

The objectives of this paper are multifold. Broadly speaking, we conduct an analysis of livestock prices in Canada and the United States. We study market integration in these markets by looking at livestock (and beef meat) trade flows, livestock prices (cointegration analysis), and then we compare the findings between the two methods. Next, we consider the concept of trade dependence and look at the effects of exogenous shocks such as the bovine spongiform encephalopathy (BSE) outbreak on livestock prices via trade dependence. Finally, we discuss potential implications of trade dependence on market integration and efficiency and relevancy of cointegration as a method in analyzing market integration. 


\section{U.S. and Canadian Livestock and Beef Industries: Market Integration Analysis}

Livestock and beef industries are important segments of agricultural sectors in both Canada and the United States. In terms of their size relative to the overall agriculture sector, however, these industries are far more important in Canada than in the United States. According to Pellow, there are 97,000 cattle farms/feedlots in Canada with farm cash receipts totaling 7.8 billion dollars or 21 percent of the total farm cash receipts in the sector. There are 20,000 people working in the beef processing industry where sales are estimated at 7.9 billion dollars. In addition, there are 32 rendering plants in Canada processing by-products and deadstock, and their estimated sales are 2.1 billion dollars. Finally, retail and food services sales of beef products are estimated at 11.1 billion dollars. Similar numbers for the United States are substantially larger than numbers for Canada. However, one must recognize the size of the U.S. relative to the Canadian agricultural sector and the economy overall being disproportionably larger. For instance, there were almost 800,000 cattle farms in the United States in 2002 (USDA, 2002 Census of Agriculture) including more than 650,000 commercial operations. Sales receipts on these farms reached almost 19 billion U.S. dollars.

\section{Market Integration - Trade Flows Approach}

Trade flows approach relies on tradability. A product is tradable between two markets if a good is actually traded between two nations or if the prospective importing market is contestable (Baumol). If either of the two is the case, the product market between those nations is integrated. Positive trade flows are sufficient condition to establish tradability, and “... non-zero trade provides prima facie evidence of market integration. In microtheoretic terms, market integration represents the Walrasian transfer of excess demand from one market to another as captured in actual or potential physical flows. Prices need not be equilibrated. If tradability is equivalent to integration, then two markets are then segmented when a product is not tradable between them. One does not need to know much economics to establish whether two markets are integrated; one just needs reliable customs data on trade patterns” (Barrett 2001, p. 20). And, reliable data on livestock and beef trade patterns between Canada and the United States are readily provided by Agriculture and Agri-Food Canada in the form of their Annual Livestock and Meat Report Schedule, ERS-USDA's Red Meat Yearbook, or by Department of Commerce, U.S. Census Bureau, Foreign Trade Statistics.

Monthly data for the period between 1996:1 and 2004:12 are considered here. The reason for starting only in 1996:1 is because it is following signing and implementation of NAFTA. Thus, on paper, U.S. and Canadian markets were fully integrated at that time and no institutional factors were supposed to be an impediment to trade between the two nations. Trade flows in both beef meat and live cattle are presented below in figures $1 \mathrm{a}-2 \mathrm{~b}$.

Trade flow numbers indicate highly integrated Canadian and U.S. livestock and beef markets until May of 2003. However, following the first BSE outbreak in Canada in May of 2003, the United States introduced a ban on imports of both live cattle and beef products from Canada. The ban on beef products lasted three months, while the ban on 
live cattle imports from Canada was not lifted until late in 2005. Similarly, as the United States experienced an occurrence of BSE in December of 2003, Canada introduced a short lasting ban on imports of U.S. live cattle and beef. Although the United States resumed exporting both live cattle and beef to Canada a few months following the ban, the levels of U.S. exports are yet to reach the pre-ban export levels. It is very clear, based on trade flows analysis, that U.S. and Canadian livestock and beef markets have not been integrated, but have been segmented following the Canadian BSE outbreak. ${ }^{2}$

\section{Market Integration - Cointegration Analysis of Livestock Prices}

Based on Goodwin (1992) and Asche, Bremnes, and Wessels (1999), price relationships in international commodity markets involve the simultaneous determination of two or more individual market prices, depending on how many markets (countries) are considered in the analysis. This raises the issue of whether individual market prices are determined by some common driving fundamentals or whether each market's price reacts to its own particular set of fundamentals or forcing variables. According to Goodwin (p. 119), “... the LOP suggests that a set of p international prices for a common good should possess a single common cointegrating vector or, equivalently, should possess p-1 stochastic trends (unit roots)." Monthly livestock price series for Canada and the United States for the period between 1996:1 and 2004:12 are shown in figure 3.

The underlying concept in testing for the existence of a long-run relationship between livestock prices in Canada and the United States, i.e., the market integration, is fairly straightforward. It has been recognized that many time series variables are nonstationary. Any equilibrium relationship among a set of non-stationary variables implies that their stochastic trends must be linked. After all, the equilibrium relationship means that the variables cannot move independently of each other. Therefore, the linkage among the stochastic trends necessitates that the variables are cointegrated (Enders; Engle and Granger; Hamilton).

Johansen's $(1991,1995)$ methodology is used to determine whether the group of non-stationary series (livestock prices in Canada and the United States in this case) are cointegrated or not. ${ }^{3}$ The presence of a cointegrating relation forms the basis of the Vector Error Correction (VEC) specification. These are VAR-based cointegration tests. Consider a VAR of order $p$ :

$$
y_{t}=A_{1} y_{t-1}+\ldots+A_{p} y_{t-p}+B x_{t}+\varepsilon_{t}
$$

where $y_{t}$ is a $k$-vector of non-stationary I(1) variables, $x_{t}$ is a $d$-vector of deterministic variables, and $\varepsilon_{t}$ is a vector of innovations. We may rewrite this VAR as,

$$
\Delta y_{t}=\Pi y_{t-1}+\ldots+\sum_{i=1}^{p-1} \Gamma_{i} \Delta y_{t-i}+B x_{t}+\varepsilon_{t}
$$

where: 


$$
\Pi=\sum_{i=1}^{p} A_{i}-I, \quad \Gamma_{I}=-\sum_{j=i+1}^{p} A_{j}
$$

Granger's representation theorem asserts that if the coefficient matrix $\Pi$ has reduced rank $r<k$, then there exists $k \times r$ matrices $\alpha$ and $\beta$ each with rank $r$ such that $\Pi=\alpha \beta$, and $\beta^{\prime} y_{t}$ is $\mathrm{I}(0)$. Here, $r$ is the number of cointegrating relations (the cointegrating rank) and each column of $\beta$ is the cointegrating vector. The elements of $\alpha$ are the adjustment parameters in the VEC model. Johansen's method is to estimate the $\Pi$ matrix from an unrestricted VAR and to test whether we can reject the restrictions implied by the reduced rank of $\Pi$.

The Augmented Dickey-Fuller (ADF) test (Dickey and Fuller) is used in order to test if the time series under consideration are stationary or not. The null hypothesis is one of the non-stationarity. The null hypothesis for both U.S. and Canadian livestock prices could not be rejected when tested at the levels at the 5\% significance level. After first differencing, the null hypothesis was rejected at the $1 \%$ significance level. Thus, both variables are I(1). Notice that in both cases exogenous variables were constant and linear trend. The lag lengths based on AIC criteria were 5 for U.S. livestock prices and 12 for Canadian livestock prices.

After establishing that both series are I(1), the cointegration analysis was pursued. The results of the cointegration analysis are reported in table 1.

The multivariate cointegration test was carried out with one lag in differences (two lags in levels). Based on the results of both trace statistics and maximum eigenvalue statistics, we can conclude that U.S. and Canadian livestock prices are cointegrated with p-values being slightly above 0.01 . More specifically, we are able to confirm that the two prices follow the same stochastic trend and are not moving independently of one another. This finding indicates, according to our theoretical specification, that U.S. and Canadian livestock markets are integrated.

\section{Market Integration - Trade Flows versus Prices}

Two different approaches to analyzing market integration clearly lead to different conclusions: trade flow analysis indicates highly integrated markets prior to May of 2003 and market segmentation following May of 2003, while price cointegration analysis is not able to make that distinction and suggests how U.S. and Canadian livestock markets have been integrated during the period 1996:1 to 2004:12. Admittedly, no transaction costs have been accounted for in the cointegration analysis. While that is certainly critical in classical trade models under the comparative or competitive advantage assumption, this is clearly the case of intra industry trade and this assumption is not as critical. The fact remains that no lay person, livestock farmers in Canada or the United States, or anyone else who was familiar with the U.S.-Canada livestock market situation in 2003 or 2004, would claim that these markets are integrated. Yet based on our 
economic tinkering with livestock prices and cointegration analysis, we seem to be able to defy common sense and conclude just that.

While livestock prices may not prove much about market integration, they can tell plenty about market efficiency. Market efficiency means the satisfaction of zero marginal benefit equilibrium conditions. Its relevancy stems from its implications on welfare and potential Pareto improvements in international economy. The standard notion of spatial equilibrium in international trade theory is one based on Samuleson and Takayama and Judge, and it implies that the dispersion of prices in two locations for an otherwise identical good is bounded from above by the cost of arbitrage between the two markets when trade volumes are unconstrained and bounded from below when trade volumes reach some ceiling value. Since trade is neither a necessary nor sufficient condition for reaching the equilibrium as defined above, it is critical to distinguish between market efficiency or the attainment of equilibrium and integration defined as tradability (when a good is traded between two or more nations) in international trade analysis. Notice that analysis of market efficiency implies use of price, transaction cost, and trade flow data (Barrett, Li, and Bailey). While the market efficiency analysis would be of great interest, it is not within the scope of this article.

\section{Trade Dependence and Livestock Prices}

One of the indicators of a country's involvement in trade is its trade dependence, as measured by the ratio of its exports plus imports to its gross domestic product (GDP). According to Bowen, Hollander, and Viaene, the average trade dependence for the period 1982-92 was as high as 350 for Singapore and as low as 13 for Myanmar. ${ }^{4}$ Some of the developed countries with high trade dependence coefficients during that time period were Hong Kong (235), Belgium (144), Netherlands (105), Taiwan (96), or Norway (81). Canada and the United Kingdom both had moderately high trade dependence coefficients of 52, while West Germany's coefficient was 55. On the other hand, the United States had one of the lowest trade dependence coefficients (20). Similar trade dependent coefficients were Japan and Iran (22), India, USSR, and Brazil (17), and Argentina (16).

It would be interesting for us to determine if similar trade dependence patterns exist in livestock and beef sectors of Canada and the United States. According to Pellow, the ratio of exported to marketed cattle in Canada for the period 2000-2002 is 25 percent; the ratio of exports to production of beef and veal is 45 percent; and, the ratio of exports to production in the total supply chain (both cattle and beef and veal) is 60 percent. Almost 85 percent of the total exports went to the United States. Our own analysis covering the period 1996:1 to 2004:12 reveals a similar pattern. Prior to the BSE incident in May of 2003, Canadian average trade dependence in the cattle and beef sector measured as the ratio of exported and imported cattle and beef to marketed cattle was above 0.60. Even as the United States lifted the ban on Canadian beef a few months after imposing it, the bans on cattle exports to the United States and beef exports to Japan (second largest market for Canadian beef exports) remained effective throughout 2003, 2004, and 2005 and affected the trade dependence coefficient to remain below the preBSE levels. U.S. trade dependence in livestock and beef products, on the other hand, was 
pretty steady at the levels of 0.15 to 0.25 during the period 1990:1 and 2004:12. The U.S. and Canadian trade dependence in livestock and beef products is showed in figures 4a and 4b.

The consideration of the trade dependence leads us to the following questions: (1) are trade dependence and price variables moving independently of one another, and if they are not, (2) what is the nature of that relationship? The assumption is that if Canadian and U.S. livestock prices alone can lead us to a conclusion of market integration (via being cointegrated), then an external disturbance of a variable (such as trade dependence) that is correlated-cointegrated with both prices will lead to a similar (statistically identical) price response in both countries. Previously discussed import bans of Canadian livestock and beef by the United States and Japan and U.S. livestock by Canada and Japan due to BSE, serve as a good example of trade dependence disturbance given the importance of the bilateral trade in livestock and beef products between Canada and the United States.

First, it is necessary to test the trade dependence variable for unit roots. ${ }^{5}$ Using the ADF test, we were unable to reject the null hypothesis for Canadian trade dependence in livestock and beef products when tested at the levels at the $5 \%$ significance level. After first differencing, the null hypothesis was rejected at the 1\% significance level. Thus, the variable is I(1). Exogenous variables were constant and linear trend. The lag lengths based on AIC criteria were 7.6

After establishing that all three series are I(1), we could pursue the cointegration analysis. The results of the cointegration analysis are reported in table 2.

The multivariate cointegration test was carried out with one lag in differences (two lags in levels). Based on the results of both trace statistics and maximum eigenvalue statistics, we can conclude that the Canadian livestock and beef trade dependence variables, U.S. and Canadian livestock prices, are cointegrated with p-values being slightly above 0.01 considering two cointegrating vectors. This finding indicates that Canadian livestock and beef trade dependence and U.S. and Canadian livestock prices are cointegrated-correlated.

We can pursue the time series analysis further in order to answer not only the question whether price and trade dependence variables are correlated but also how trade dependence changes have impacted livestock prices. In other words, we can refocus from the issue whether these events are correlated to quantifying the measure of how they are related. The Vector Error Correction (VEC) model is appropriate in the case with non-stationary series that are known to be cointegrated. As in traditional Vector Autoregression (VAR) analysis, Lutkepohl and Reimers showed that innovation accounting (i.e., impulse responses) can be used to obtain information concerning the interactions among the variables. As a practical matter, the two innovations $\varepsilon_{y t}$ and $\varepsilon_{z t}$ may be contemporaneously correlated if $y_{t}$ has a contemporaneous effect on $z_{t}$ and/or $z_{t}$ has a contemporaneous effect on $y_{t}$. In obtaining impulse response functions, Choleski decomposition is used to orthogonalize the innovations. The impulse responses are 
sensitive to the ordering of variables. Economic theory sometimes provides the rationale for the ordering. Usually, there is no such a priori knowledge. ${ }^{7}$ Due to lack of economic theory in this case, the ordering was determined solely based on the research questions asked. The graphs in figure 5 trace out the effects of one-unit shocks to all $\varepsilon_{s}$ on the time paths of the CAP, USP, and CATD sequences. While all results are interesting and informative, we are most interested in the effects of one unit-shocks in $\varepsilon_{C A T D, t}$ on CAP and USP sequence. That is also the reason why we ordered the variables as the following: CAP, CATD, USP and USP, CATD, CAP, respectively. Results from the impulse response analysis are presented in figure 5 and figure 6.

Again, we are most interested in the effects of one unit-shocks in $\varepsilon_{C A T D, t}$ on CAP sequence (Graph denoted Response of CAP to CATD in figure 5) and USP sequence (Graph denoted Response of USP to CATD in figure 6). It is obvious that a shock in $\varepsilon_{C A T D, t}$ led to very different responses by CAP and USP. Let us first consider the Canadian livestock price (CAP) case. The impulse response function analysis indicates that Canadian livestock price will move in the same direction as the change-shock in trade dependence. For instance, in the case of sudden drop in trade dependence, Canadian livestock prices will drop as well and will not return completely to the original equilibrium level even after 36 months. That is exactly the pattern observed following the U.S. ban on imports of livestock and beef from Canada. U.S. livestock prices, on the other hand, move in the opposite direction from Canadian trade dependence. For example, in the case of sudden shock causing a drop in Canadian trade dependence, U.S. livestock prices would increase and, although slowly declining, would not converge to the original equilibrium price even after 36 months. Indeed, U.S. livestock prices increased following the ban of imports from Canada and remained high ever since.

\section{Implications and Conclusions}

Time-series analysis of Canadian and U.S. livestock prices leads us to some very ambiguous conclusions considering market integration. Cointegration of Canadian and U.S. livestock prices points to the existence of market integration in the period 1996:1 to 2004:12. And that is in spite of the fact that the trade flows of livestock and beef products were non-existent for many months in 2003 and 2004 (suggesting market segmentation) due to livestock/beef import bans by both countries due to BSE. Moreover, Canada's trade dependence in livestock and beef is cointegrated with Canadian and U.S. livestock prices. However, as the trade dependence variable is shocked, the effects on Canadian and U.S. prices are completely opposite. Yet one would expect that in an integrated market the price responses to an exogenous shock would be similar or statistically identical. This result reinforces the case against the use of cointegration in determining presence (or absence) of market integration. As Lence and Barry (p. 889) pointed out in their study, “... cointegration tests ... may be used to draw inferences about preferences and endowment process, but not for assessing market integration and/or efficiency.” Likewise, for those who keep identifying the LOP with market integration, a suggestion from Miljkovic (p. 137) is still valid: "Thus, a great deal 
of caution is necessary before making any conclusion or decision regarding the LOP in any commodity market.”

Empirical results in this article raise some very difficult questions. Gains from trade are one of the cornerstones of economic theory. Yet, once a country is very trade dependent, the prices in it are much more vulnerable to exogenous shocks that reduce the trade flows. Canadian livestock prices plummeted and stayed low following the BSE incident and U.S. (and Japanese) import bans on Canadian livestock and beef. Given the long cycles and high sunk cost in the livestock and beef industry, immediate adjustment (reduction in production) for Canadian producers was difficult and always unlikely. Moreover, the possibility of import bans being lifted in the near future may have further shaped their expectations and prolonged the decisions on herd reduction. In the meanwhile, U.S. prices increased following Canada's trade dependence shock due to BSE and remained above the original long-run equilibrium price. A view by Feuz sums up the situation in the U.S. cattle markets: "In spite of all of this news - good, bad, or ugly based on your perspective - the cattle market was sensational in 2005. USDA Choice box beef prices averaged over $\$ 1.44$ per pound for the year. That compares to an average price of $\$ 1.41$ last year and $\$ 1.28$ for the past five years. The spread between Choice and Select prices was in line with the five-year average. That increase in average price occurred even though beef production was about a half of a percent larger. Fed cattle prices in Nebraska averaged $\$ 87$ per cwt. in 2005, compared to $\$ 85$ in 2004, and just over $\$ 75$ per cwt for the previous five years. Yearling and calf prices in Nebraska were also at record high levels for the year. The price for 750 pound steers averaged $\$ 117$ per cwt. and 550 pound steer calves averaged over \$138 per cwt. for the year. Prices last year were about $\$ 110$ and $\$ 127$ and the five-year average was $\$ 94$ and \$109 for yearlings and calves, respectively.” This whole situation is most interesting since reduction in trade by Canada led to lower prices in Canada, thus decreasing producer welfare but increasing consumer welfare. And trade theory clearly teaches us about the gains from (free) trade and the prominent role of the increase in consumer welfare in it. The issues remain with the structure and size of the Canadian livestock and beef industry that overgrew the needs of the domestic market long ago and is geared towards exports. The problem is what to do when the exports cease? 


\section{References}

Agriculture and Agri-Food Canada. Various years. Annual Livestock and Meat Report Schedule. Available at: http://www.agr.gc.ca/redmeat/almrcalendar.htm.

Almas, L.K., W.A. Colette, and S.H. Amosson. "BSE, U.S. Beef Trade and Cattle Feeding Industry.” Paper presented at the 2005 SAEA Annual Meeting, Little Rock, Arkansas, February 5-9, 2005.

Ardeni, P.G. "Does the Law of One Price Really Hold for Commodity Prices?” Amer. J. of Agr. Econ. 71(3):661-69, 1989.

Asche, F., H. Bremnes, and C.R. Wessels. "Product Aggregation, Market Integration, and Relationships between Prices: An Application to the World Salmon Markets.” Amer. J. Agr. Econ. 81(3):568-581, 1999. . "Product Aggregation, Market Integration, and Relationships between Prices: An Application to the World Salmon Markets: Reply.” Amer. J. Agr. Econ. 83(4):1090-1092, 2001.

Baffes, J. "Some Further Evidence on the Law of One Price: The Law of One Price Still Holds.” Amer. J. of Agr. Econ. 68(4):1264-73, 1991.

Barret, C.B. "Market Analysis Methods: Are Our Enriched Toolkits Well Suited to Enlivened Markets?” Amer. J. of Agr. Econ. 78(3): 825-29, 1996. . "Measuring Integration and Efficiency in International Agricultural Markets." Rev. of Agr. Econ. 23(1):19-32, 2001.

Barrett, C.B., J.R. Li, and D.V. Bailey. "Factor and Product Market Tradability and Equilibrium in Pacific Rim Pork Industries.” J. of Agr. \& Res. Econ. 25(1):68-87, 2000.

Baumol, W.J. “Contestable Markets: An Uprising in the Theory of Industry Structure.” Amer. Econ. Rev. 72(1): 1-15, 1982.

Bowen, H.P., A. Hollander, and J.M. Viaene. Applied International Trade Analysis. The University of Michigan Press, Ann Arbor,MI, 1998.

Broda, C., and D. Weinstein. “Globalization and the Gains from Trade.” National Bureau of Economic Research, NBER Working Paper \# 10314, 2004.

- "Are We Underestimating the Gains from Globalization for the United States?" Current Issues in Econ. \& Finance 11(4):1-7, 2005.

Dickey, D.A., and W.A. Fuller. "Distribution of the Estimators for Autoregressive Time Series with a Unit Root.” J. of the Amer. Stat. Assoc. 74: 427-431, 1979.

Economic Research Service. Various Years. Red Meat Yearbook, U.S. Department of Agriculture, Available at: http://www.ers.usda.gov/Data/sdp/view.asp?f=livestock/94006/\&arc=C.

Enders, W. Applied Econometric Time Series. New York: John Wiley \& Sons, Inc., 1995.

Engle, R.F., and C.W.J. Granger. "Co-integration and Error Correction: Representation, Estimation, and Testing.” Econometrica 55(2):251-276, 1987.

Fackler, P.L., and B.K. Goodwin. "Spatial Price Analysis.” In B.L. Gardner \& G.C. Rausser (Eds.), Handbook of Agricultural Economics. Amsterdam: Elsevier Science, 2001, pp. 971-1024.

Feuz, D.M. “2005 Cattle Market Review and 2006 Preview.” Available at: http://www.panhandle.unl.edu/feuz/index.html, (Accessed on January 14, 2006). 
Frankel, J.A., E. Stein, and S.J. Wei. "Trading Blocs and the Americas: The Natural, the Unnatural and Supernatural.” J. of Dev. Econ. 47(1):61-95, 1995.

Goodwin, B.K. "Multivariate Cointegration Tests and the Law of One Price in International Wheat Markets.” Rev. of Agr. Econ. 14(1):117-24, 1992.

Goodwin, B.K., and N.E. Piggott. "Spatial Market Integration in the Presence of Treshold Effects.” Amer. J. of Agr. Econ. 83(2):302-317, 2001.

Hamilton, J.D. Time Series Analysis. Princeton, NJ: Princeton University Press, 1994.

Jin, H.J., A. Skripnitchenko, and W.W. Koo. "The Effects of the BSE Outbreak in the United States on the Beef and Cattle Industry.” Special Report 03-4, Center for Agricultural Policy and Trade Studies, North Dakota State University, Fargo, ND, 2004.

Johansen, S. "Estimation and Hypothesis Testing of Cointegration Vectors in Gaussian Vector Autoregressive Models.” Econometrica 59(6): 1551-1580, 1991. . Likelihood-Based Inference in Cointegrated Vector Autoregressive Models. Oxford: Oxford University Press, 1995.

Knetter, M.M., and M.J. Slaughter. "Measuring Product-Market Integration.” Working paper no. 6969, NBER, Cambridge, MA, February 1999.

Krugman, P. “Growing World Trade: Causes and Consequences.” Brookings Papers Econ. Act.: 327-77, 1995.

Lence, S., and B. Falk. 2005. “Cointegration, Market Integration, and Market Efficiency.” J. of Internatl. Money \& Fin. 24: 873-890, 2005.

Lutkepohl, H., and H.E. Reimers. "Impulse Response Analysis of Cointegrated Systems.” J. of Econ. Dynam. \& Control 16(1): 53-78, 1992.

MacKinnon, J.G., A.A. Haug, and L. Michelis. "Numerical Distribution Functions of Likelihood Ratio Tests for Cointegration.” J. of Appl. Econ. 14:563-577, 1999.

Mattson, J.W., H.J. Jin, and W.W. Koo. "The Effect of Lost Exports on U.S. Beef Prices.” AAE Report No. 558, Center for Agricultural Policy and Trade Studies, North Dakota State University, Fargo, ND, 2005.

McNew, K., and P.L. Fackler. "Testing Market Equilibrium: Is Cointegration Informative?” J. Agr. And Resour. Econ. 22, no. 2(1997):191-207.

Miljkovic, D. “The Law of One Price in International Trade: A Critical Review.” Rev. Agr. Econ. 21, no. 1(1999):126-39.

Miljkovic, D., and R.J. Paul. "Product Aggregation, Market Integration, and Relationships between Prices: An Application to the World Salmon Markets: Comment.” Amer. J. Agr. Econ. 83(4): 1087-1089, 2001.

. "Regionalism and Trade Creation: The Case of NAFTA.” In P. Lynn Kennedy and Won W. Koo (Eds.). Agricultural Trade Policies in the New Millennium. New York: The Haworth Press, Inc., pp. 273-286, 2002.

—. "Agricultural Trade in North America: Trade Creation, Regionalism and Regionalization.” Aust. J. of Agr. \& Res. Econ. 47(3):349-366, 2003.

Pellow, S. 2005. "BSE Modelling: Economic Sectoral Analysis.” Paper presented at the 2005 IATRC Annual Meeting, San Diego, CA, December 4-6, 2005.

Samuleson, P.A. "Spatial Price Equilibrium and Linear Programming." Am. Econ. Rev. 42(3): 283-303, 1952. 
Sexton, R., C. Kling, and H.F. Carman. "Market Integration, Efficiency of Arbitrage and Imperfect Competition: Methodology and an Application to U.S. Celery.” Amer. J. of Agr. Econ. 73(2):568-80, 1991.

Sims, C. "Macroeconomics and Reality.” Econometrica 48(1):1-49, 1980.

—. "Bayseian Skepticism on Unit Root Econometrics." J. of Econ. Dynam. \& Control 12(2):463-474, 1988.

Takayama, T., and G.G. Judge. Spatial and Temporal Price Allocation Models. Amsterdam: North Holland, 1971.

U.S. Department of Agriculture. 2002 Census of Agriculture. National Agricultural Statistics Service, Washington, DC.

Wieck, C., and D. Holland. "The Effect of the BSE Outbreak in Canada on the U.S. Economy.” Paper presented at the 2005 IATRC Annual Meeting, San Diego, CA, December 4-6, 2005.

Zanias, G.P. “Testing for Integration in European Community Agricultural Product Markets.” J. of Agr. Econ. 44(3):418-27, 1993. 


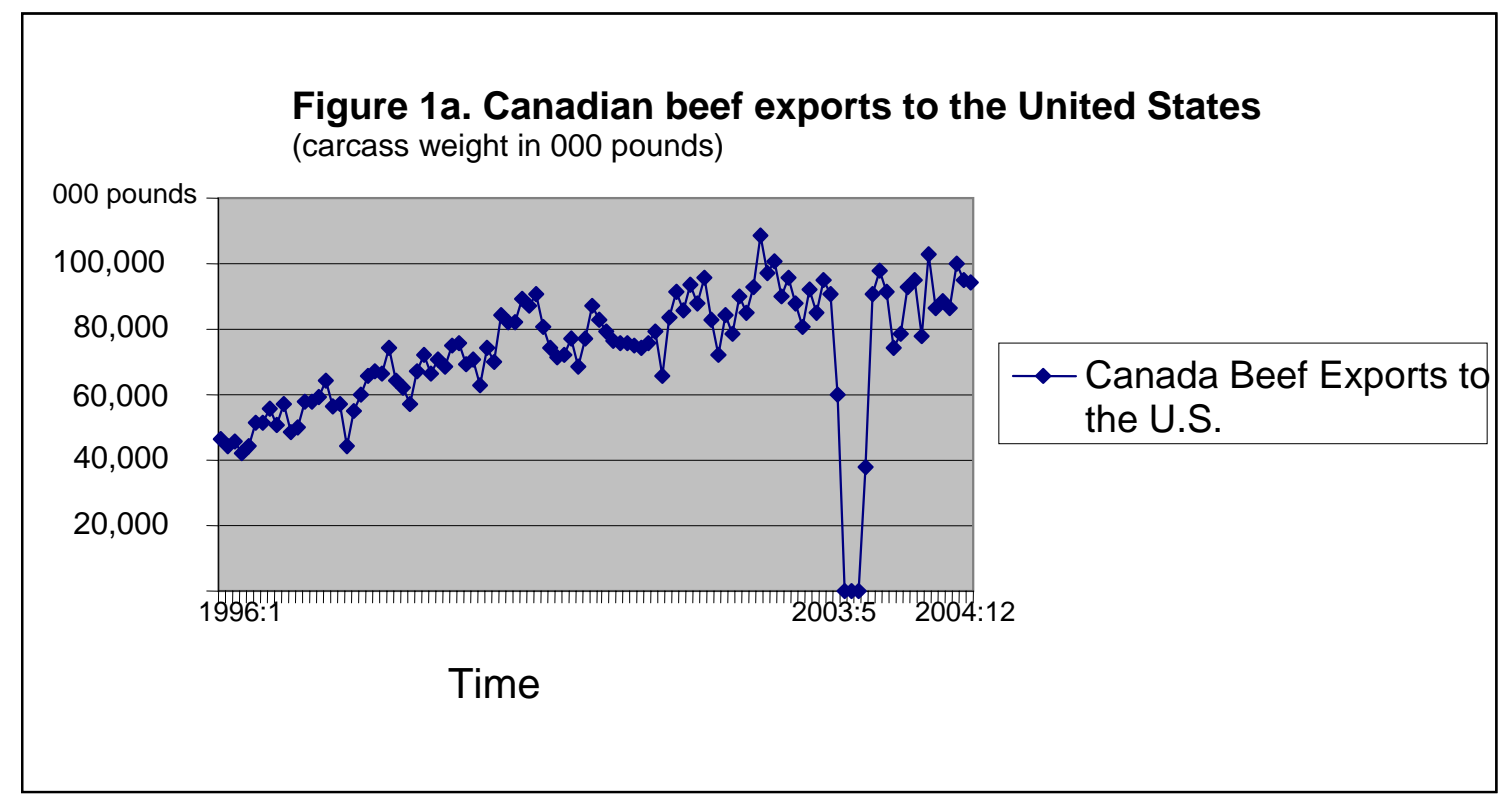

Figure 1b. Canadian live cattle exports to the United States

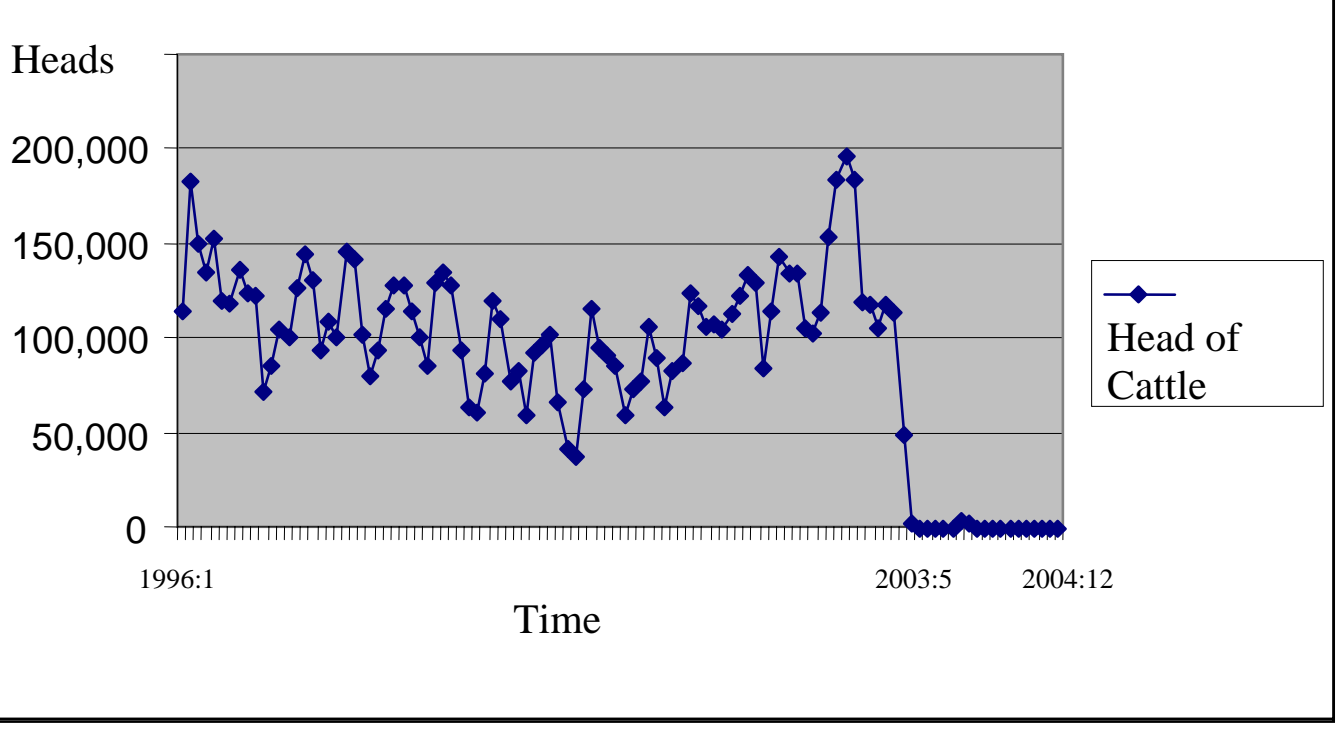

Source: Agriculture and Agri-Food Canada, Annual Livestock and Meat Report Schedule. 


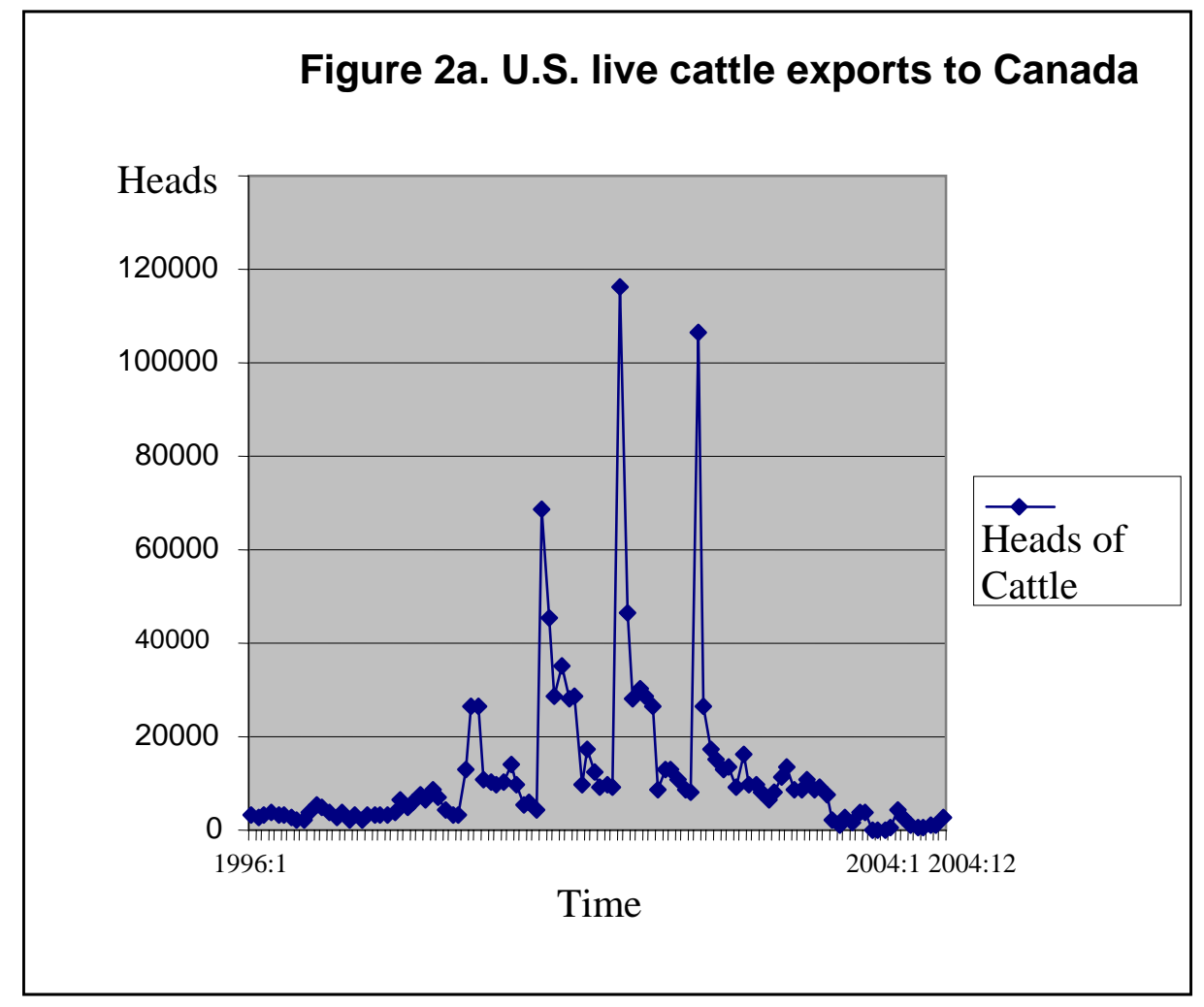

Figure 2b. U.S. beef exports to Canada

(in Metric Tons)

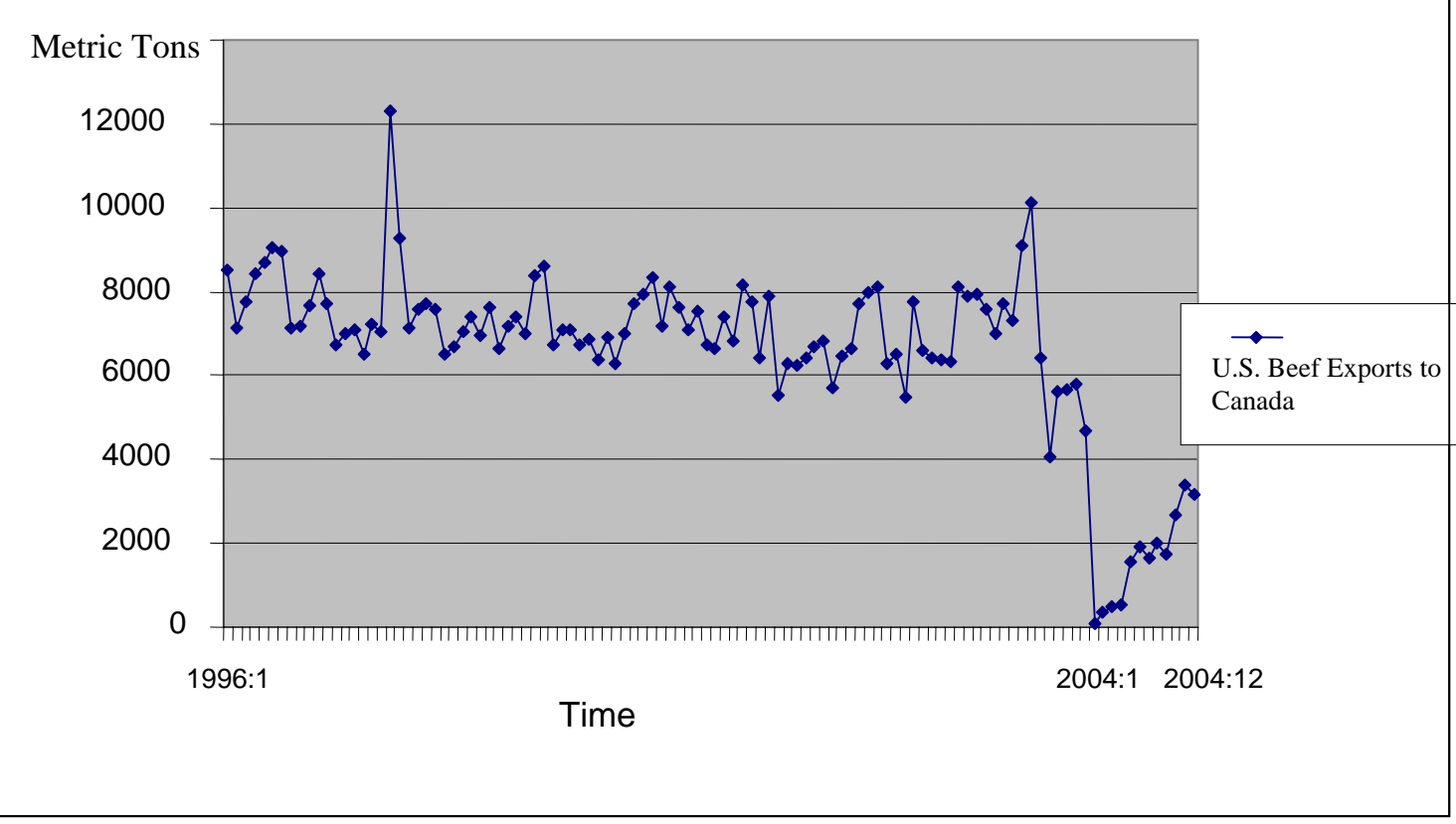

Source: Department of Commerce, U.S. Census Bureau, Foreign Trade Statistics. 
Figure 3. U.S. and Canadian livestock prices

U.S. dollars per 100 pounds

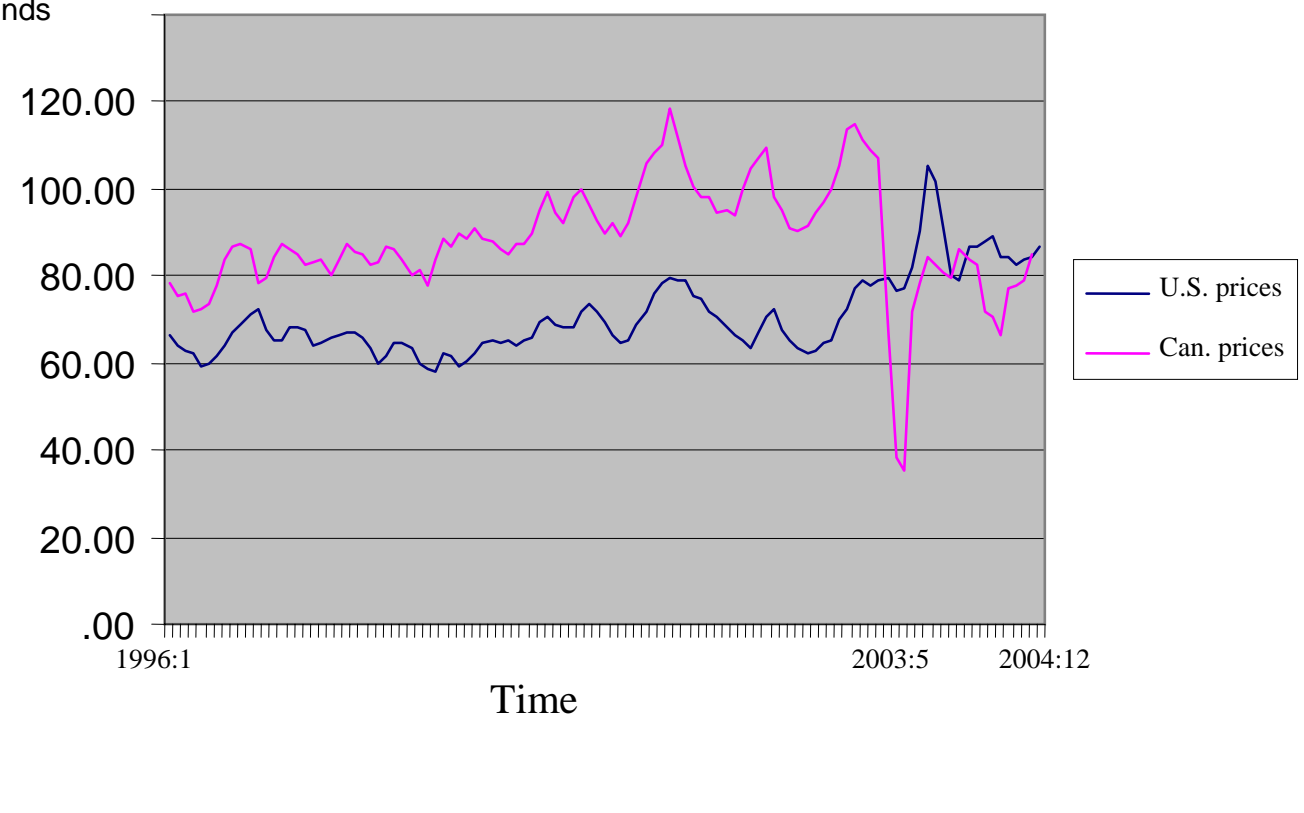

Note: U.S. prices are represented by Nebraska Steer Price, Choice 2-4, 1100-1300 pounds. Canadian prices are represented by Alberta Steers Monthly Weighted Average Price.

Sources: ERS-USDA's Red Meet Yearbook and Agriculture and Agri-Food Canada, Annual Livestock and Meat Report Schedule. 
Figure 4a. Canada - livestock and beef trade dependence

Trade Dependence

Coefficient

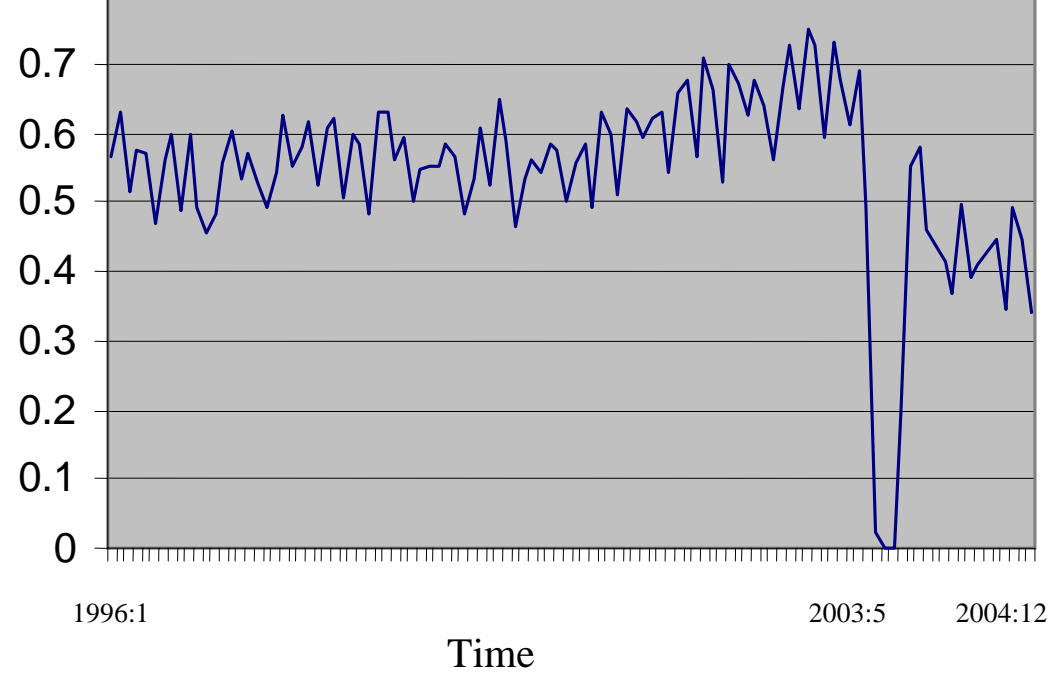

Figure 4b. U.S. - livestock and beef trade dependence

Trade

Dependence Coefficient

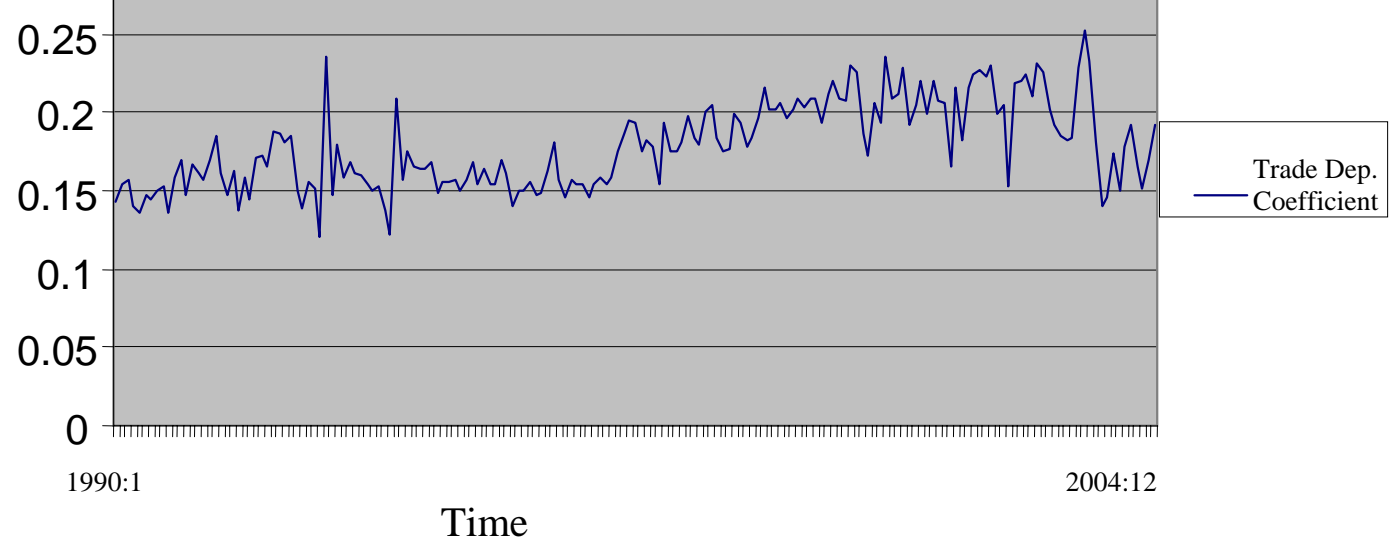

Sources: Author's calculation based on ERS-USDA's Red Meet Yearbook and Agriculture and Agri-Food Canada, Annual Livestock and Meat Report Schedule. 
Figure 5. Impulse response functions for the sequence CAP, CATD, USP

Response to Cholesky One S.D. Innovations \pm 2 S.E.
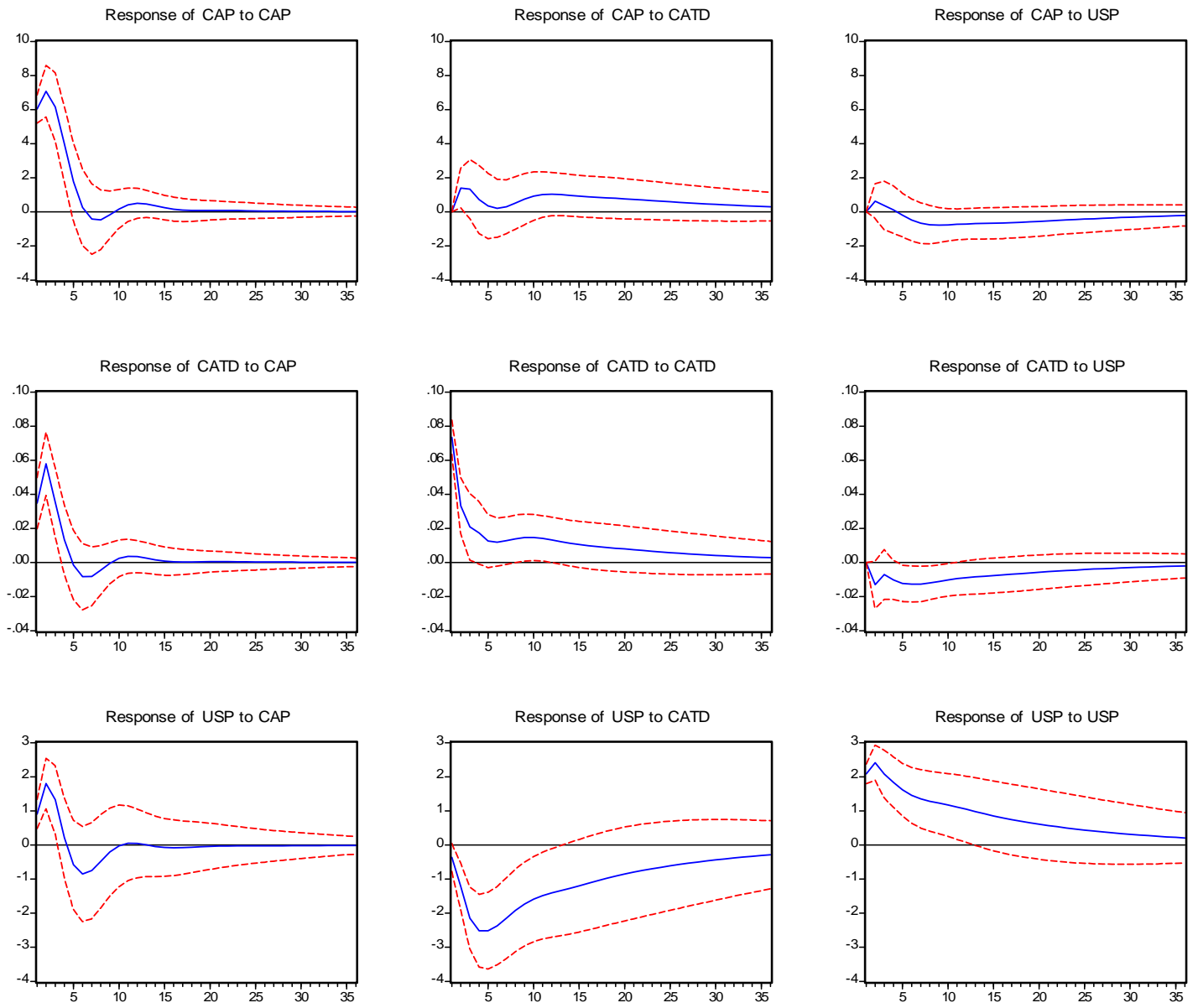

Note: CAP, CATD, and USP stand for Canadian livestock prices, Canadian beef and livestock trade dependence, and U.S. livestock prices respectively. 
Figure 6. Impulse response functions for the sequence USP, CATD, CAP
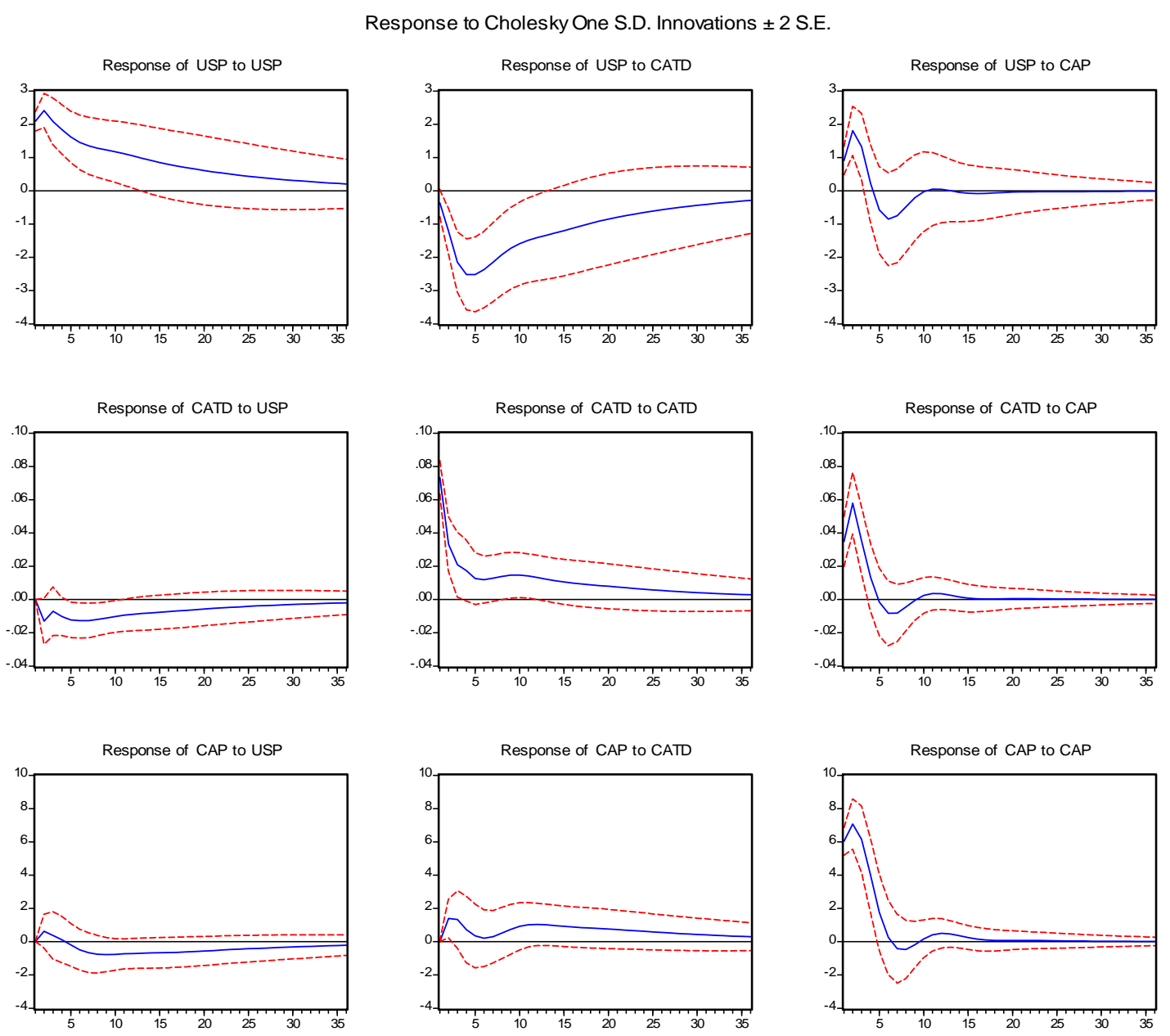

Note: CAP, CATD, and USP stand for Canadian livestock prices, Canadian beef and livestock trade dependence, and U.S. livestock prices respectively. 
Table 1 Cointegration Analyses - Multivariate Johansen Test between CAP and USP

\begin{tabular}{lcccccc}
\hline $\mathrm{H}_{0}:$ rank $=\mathrm{p}$ & $\begin{array}{c}\text { Trace Test } \\
\text { Statistic }\end{array}$ & $\begin{array}{c}\text { 0.05 Critical } \\
\text { Value }\end{array}$ & $\mathrm{p}$-value $^{2}$ & $\begin{array}{c}\text { Max. Eigenvalue } \\
\text { Statistic }\end{array}$ & $\begin{array}{c}0.05 \text { Critical } \\
\text { Value }\end{array}$ & $\mathrm{p}^{\text {-value }}{ }^{2}$ \\
$\mathrm{p}=0^{1}$ & 28.4153 & 18.3977 & 0.0014 & 22.3697 & 17.1476 & 0.0080 \\
$\mathrm{p} \leq 1^{1}$ & 6.0455 & 3.8414 & 0.0139 & 6.0455 & 3.8414 & 0.0139 \\
& & & & & & \\
\hline
\end{tabular}

Note: Both Trace and Max. Eigenvalue Tests indicate one cointegrating equation at the 0.05 level. CAP and USP stand for Canadian livestock prices and U.S. livestock prices respectively.

${ }^{1}$ Denotes rejection of the hypothesis at the 0.05 level.

${ }^{2}$ MacKinnon, Haug, and Michelis p-values. 
Table 2. Cointegration Analyses - Multivariate Johansen Test between CATD, CAP and USP ${ }^{1}$

\begin{tabular}{|c|c|c|c|c|c|c|}
\hline$\overline{\mathrm{H}_{0}: \operatorname{rank}=\mathrm{p}}$ & $\begin{array}{c}\text { Trace Test } \\
\text { Statistic }\end{array}$ & $\begin{array}{l}0.05 \text { Critical } \\
\text { Value }\end{array}$ & p-value ${ }^{2}$ & $\begin{array}{l}\text { Max. Eigenvalue } \\
\text { Statistic }\end{array}$ & $\begin{array}{c}0.05 \text { Critical } \\
\text { Value }\end{array}$ & p-value ${ }^{2}$ \\
\hline $\mathrm{p}=0^{1}$ & 67.4472 & 35.0109 & 0.0000 & 48.6156 & 24.2520 & 0.0000 \\
\hline $\mathrm{p} \leq 1^{1}$ & 18.8316 & 18.3977 & 0.0435 & 17.2978 & 17.1476 & 0.0478 \\
\hline $\mathrm{p} \leq 2^{1}$ & 6.5337 & 3.8414 & 0.0106 & 6.5337 & 3.8414 & 0.0106 \\
\hline
\end{tabular}

Note: Both Trace and Max. Eigenvalue Tests indicate two cointegrating equations at the 0.05 level. CAP, CATD, and USP stand for Canadian livestock prices, Canadian beef and livestock trade dependence, and U.S. livestock prices respectively.

${ }^{1}$ Denotes rejection of the hypothesis at the 0.05 level.

2 Denotes MacKinnon, Haug, and Michelis p-values. 


\section{Footnotes:}

${ }^{1}$ See Miljkovic and Fackler and Goodwin for review of the market integration/LOP literature.

2 There are several studies concerning the economy-wide impact of the U.S. BSE outbreak (e.g., Jin, Skripnitchenko, and Koo), the loss of U.S. export markets due to the BSE outbreak (e.g., Almas, Colette, and Amosson; Mattson, Jin, and Koo), or the effects of the Canadian border closure on the U.S. economy (e.g., Wieck and Holland). None of these or any other studies concerning BSE, to the best of our knowledge, addressed the issue of market integration.

${ }^{3}$ Considering that there are only two markets in this case, one could employ the EngleGranger bivariate cointegration procedure instead of the Johansen procedure. Yet it has been recognized in the literature that multivariate cointegration is more general and, thus, we choose it for that reason.

4 The trade dependence of several countries exceeds $100 \%$. This reflects that these countries engage primarily in warehouse trade, i.e., these countries are primarily conduits for the trans-shipment of goods from the country of production to the country of consumption.

${ }^{5}$ Notice that we have already determined that CAP and USP are I(1).

${ }^{6}$ U.S. trade dependence is $\mathrm{I}(0)$. Given that cointegration necessitates that the variables be integrated of the same order (Enders, p. 374), we could not proceed with the cointegration analysis of livestock prices in Canada and the United States which are both I(1) and U.S. trade dependence which is I(0).

7 The very idea of imposing a structure on a VAR system seems contrary to the spirit of Sims' $(1980,1988)$ argument against “incredible identifying restriction.” Unfortunately, there is no simple way to circumvent the problem; identification necessitates imposing some structure on the system. The Cholesky decomposition provides a minimal set of assumptions that can be used to identify the primitive model. 